DOI https://doi.org/10.18551/rjoas.2018-12.26

\title{
STRATEGY OF AGROTOURISM POTENTIAL DEVELOPMENT IN AGROPOLITAN SENDANG AREA, TULUNGAGUNG EAST JAVA PROVINCE OF INDONESIA
}

\author{
Rokani Lutvita Erya* \\ Master Program of Enviromental and Development Studies, University of Brawijaya, \\ Malang, Indonesia \\ Hakim Luchman \\ Department of Biology, Faculty of Mathematics and Natural Sciences, \\ University of Brawijaya, Malang, Indonesia
}

\author{
Setyowati Endah \\ Postgraduate Program of Environmental Studies, University of Brawijaya, Malang, Indonesia \\ *E-mail: lutvitaerya@gmail.com
}

\begin{abstract}
Since 2004, Sendang district has been designated as an agropolitan area. However, its development still faces so many obstacles until now, and result in a low economic income. The aims of this study are to analyze the potential for the development of agrotourism in Sendang as well as formulate appropriate strategies in accordance with its potential. The research method combined both qualitative and quantitative approach. A qualitative approach is used to explore the potential that can be developed as agrotourism, while a quantitative approach is used to formulate the most appropriate agrotourism development strategies. Data obtained from direct observation, semi-structured interview with stakeholders, and distributing questionnaires to 50 visitors. Then, the obtained results were analyzed using the SWOT strategy with IFAS and EFAS analysis. The results show that there are two villages that have more potential than the other villages, both of them are Geger Village and Sendang Village. Potentials found in Geger Village are agriculture, livestock, plantation, ornamental flower cultivation, natural tourism, historical and cultural tourism. While the potentials that exist in Sendang Village are livestock sector, historical tourism, craft and arts sector. The direction of the strategy for the development of agrotourism in the Agropolitan Sendang Area is in quadrant I. An aggressive strategy using the strength opportunity strategy (SO) is selected as the best strategy for Sendang. The strategy that will be developed is collecting data on tourism potential and tourist attraction objects; improving the management by involving the community; strengthening the synergy between local governments, private sector, and the surrounding community; actively conducting promotions and socialization.
\end{abstract}

\section{KEY WORDS}

Agropolitan Sendang area, agrotourism development, potential, strategy, SWOT.

Agropolitan Area is one of the approaches to develop rural-base agriculture (Sunfianah and Haryono, 2014). The aim is to make the community or farmers able to sell their agricultural products directly, and reduce production and marketing costs (Syahrini, 2001). The realization of agribusiness efforts in rural and urban areas can accelerate regional economic development. The target of developing the agropolitan area is the empowerment of the community as agribusiness actors, the development of superior agricultural commodities, the institutional development and service providers for farmers, and the development of facilities and infrastructure (Buang, et al., 2011). So far, the Agropolitan Program has not been widely known by the community and various facilities have not been optimally utilized (Farhanah and Prajanti, 2015). Agrotourism Area is a place where tourists can spend their holidays in the village by enjoying agricultural atmosphere at an economical cost. In addition, 
it utilizes agricultural sector and allows tourists to gain knowledge, build business collaboration related to agriculture, and relax (Fleischer and Tchetchik, 2006). The transformation of agricultural areas into agrotourism will benefit the local society, as they will still be able to perform agricultural activities while on the other hand gain income from tourist visits. The interesting part of developing agrotourism in Indonesia is each region has various options to highlight different agrotourism attractions, including agricultural activity and local culture (Srivastava, 2016).

Since 2001, several regencies in East Java have implemented agropolitan development programs, one of them is Tulungagung regency. The agricultural sector in Tulungagung Regency has the potential to be the main capital for regional development. Based on the Decree of the regent No. 16 of 2004, Sendang has been designated as an agropolitan area with most of the population working as farmers and breeders. The implementation of agropolitan program in Sendang has a goal to improve the regional economy through superior commodities of horticulture and dairy cattle (Region Regulation of Tulungagung, 2004). Based on the Tulungagung Regent Regulation No. 24 of 2014, the aim of agropolitan development is to improve the regional economy and community welfare. However, community's income in Sendang is still low. Due to various obstacles faced by agropolitan development in Sendang (Prasetiya, 2015). Accordingly, potential exploration must be accompanied by planning and development strategies.

Therefore, it is necessary to explore other potential so that the economy of Sendang's community will significantly be better. One of the potential is by developing agrotourism and utilizing agricultural products that already exist in the Agropolitan Sendang Region. So, this study aims to analyze the agrotourism potential and formulate appropriate strategies to develop agrotourism in accordance with the potential of the agropolitan sendang region.

\section{METHODS OF RESEARCH}

Study Site. This research was conducted in the Agropolitan Sendang Region in Sendang District, Tulungagung Regency, East Java Province of Indonesia for 5 (five) months from May to September 2018. Sendang District has 11 villages and is located in the northwest of Tulungagung Regency.

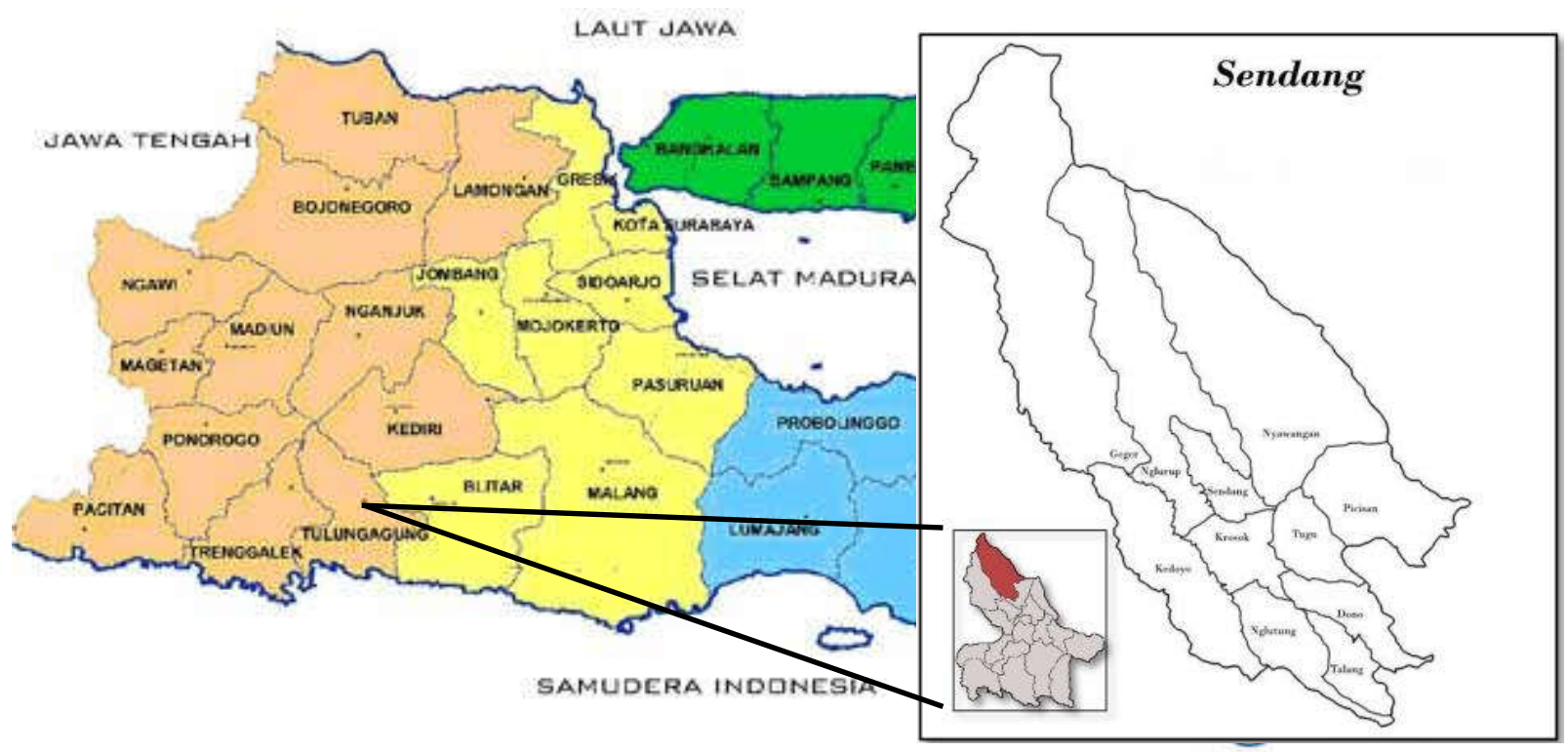

Figure 1 - Location of Studied Area

Data Collection. This research applied mixed method that combined two approaches, namely qualitative and quantitative. Qualitative approach was used to explore the potential that can be developed as agrotourism, while quantitative approach was used to analyze the strategy of developing agrotourism in Agropolitan Sendang Region. This study collected both 
primary and secondary data. Primary data was obtained from direct observations in the field, distributing questionnaires to tourists, and performing semi-structured interview to communities around the study site. Whereas secondary data was obtained from relevant agencies and literature studies. Respondents in this study were people around agrotourism, tourists visiting Sendang Sub-district, and related agencies. The snowball sampling technique was conducted to select the respondents.

Data Analysis. Observation and interview data were analyzed using qualitative descriptive approach. While data of questionnaire was analyzed using quantitative descriptive approach. Strategy development was planned using SWOT analysis which consists of some aspects, including strength (S) and opportunities (O), weaknesses (W) and threats (T). An assessment (weighting) was measured by using IFAS-EFAS analysis to determine the basic concepts of agrotourism development. Then, the result was presented in the form of a quadrant to obtain an appropriate development strategy (Parmawati, et al., 2018).

\section{RESULTS AND DISCUSSION}

The potential of Agropolitan Sendang Area. Sendang district has a lot of potentials, including natural resources and social culture that can be developed into tourism. From eleven villages in Sendang district, two of them have enormous potency, namely Geger village and Sendang village. Some of the potency has already begun to be developed but still not managed properly. However, there are still plenty hidden potentials which deserve to be developed better.

Geger Village. As many as six potentials can be developed into various attractions in Geger village (Table 1). The first potency is the agricultural sector, as Geger village is the largest crops producer in Sendang district. Based on data, there are at least 14 types of crop in Geger village and total of 981 community work as farmers.

Table 1 - The Potential Attraction of Geger village

\begin{tabular}{ll}
\hline \multicolumn{1}{c}{ Potency } & \multicolumn{1}{c}{ Tourist attraction } \\
\hline Agriculture & Producing vegetable and fruit noodles \\
& Organic product \\
& Beautiful scenery \\
Livestock & Milking \\
& Training on fertilizer production \\
Plantation & Tea plantation \\
& Coffee plantation \\
& Food truck of OMAH KOPI \\
& Producing banana chips and "sale pisang" \\
Ornamental flower cultivation & Photo spot \\
& Defloration \\
Natural tourism & Tracking \\
& Waterfall \\
& Beautiful scenery \\
Historical and Cultural tourism & Swimming pool \\
& Traditional ceremony of Buceng Robyong \\
\end{tabular}

The community of Geger relies on mountain slopes for agriculture, because it's supported by enough water capacity to plant various crops. As an agricultural center, Geger village has the potential to be used for educational purpose related to crops cultivation. Some of the crops are processed into food, such as vegetable noodles, banana chips, and "sale pisang". The second potency is in the livestock sector, as dairy farming contribute a lot in the economic of Geger village. In fact, Geger village is the largest good quality milk producer in Tulungagung. Moreover, Geger village has suitable weather to support dairy farming. Geger village has the most dairy farmers (865 farmers) among other villages in Sendang district with approximately 3792 dairy cattles. The third potencies are the tea and coffee plantation as the main commodity in Agropolitan Sendang Area. Geographically, Sendang located in 
the highland which has a stable temperature and humidity for high-quality tea and coffee production. Sendang district produced various tea products, including red tea, green tea, and herbal tea. According to Koththagoda and Dissanayake (2017), recently, many countries are developing tea as tourist attraction. Tea tourism is a tourist concept that emphasizes recreation while gaining experience and education. Tea has its own historical identity, tradition and culture that can attract tourists to come and visit. Meanwhile, coffee varieties that can be found are Robusta, Arabica, and Liberika. Sendang's coffee is planted at the elevation of 700-1200 masl at the foot of Wilis mountain. According to Baffes (2005), coffee is a valuable commodity after oil as it can be enjoyed by all people. $90 \%$ of coffee production is very influential on the country's economy. The existence of coffee tourism is one way that can overcome the economic difficulties faced by farmers.

The fourth potency is ornamental flower cultivation in Geger village, which is the largest producer of ornamental flowers, especially Chrysanthemums. This flower has attractive shapes and colors which makes it popular among ornamental plant's lover. Besides its popularity as ornamental plant, Chrysanthemum also functions as medicine which makes its economic value. Accordingly, Chrysanthemum cultivation can be a promising business (Prasetio, 2010). The visitors do not need to pay for the entrance ticket, however visitors can buy these flowers at an average price of Rp. 15.000,- /10 flowers. Moreover, beautiful greenhouse is also available for the visitors. The fifth potency is Lawean waterfall, a natural tourism in Sendang district. This waterfall is originated from the slopes of Mount Wilis which has elevation of 1200 masl. Visitors need to walk for $3 \mathrm{~km}$ to reach the waterfall. Lawean waterfall offers a calm atmosphere, cool and fresh air, and natural view that is wellpreserved. The hill with the flow of beautiful waterfall complements the beauty of Lawean waterfall. More interestingly, local beliefs, stated that swimming in Lawean can cure all diseases, also attract more visitors to come. The last potency of Geger village is its historical and cultural tourism. The well-known historical tourism in Sendang is Penampihan temple. Penampihan Temple used to be a place of worship since the era of Mataram Hindu, Singosari, Kediri to Majapahit. "Wilis" was engraved on the inscription which later known as the name of Mount Wilis. Every 1st Suro there is always a Buceng Robyong ceremony centered on Penampihan Temple. This ceremony is carried out as a form of preservation of springs. This ceremony is held every 1 year.

Table 2 - The Potential Attraction of Sendang village

\begin{tabular}{ll}
\hline \multicolumn{1}{c}{ Potency } & Milking \\
\hline Livestock & Pasteurization \\
& Biogas training \\
& Training on fertilizer production \\
& Making milk products \\
& Mbah Bodo grave site \\
Historical tourism & Arga Wilis guest house \\
& Traditional ceremony of Siraman Barongan \\
Craft and Art sector & Making "Batik Tulis" of Sendang \\
& Karawitan \\
\hline
\end{tabular}

Sendang Village. The potency of Sendang village is less than Geger village. Sendang village only has 3 potential sectors, including livestock, historical tourism, craft and art sector (Table 2). The most prominent livestock sector of Sendang District is the dairy farm, as the milk quality is as good as the one produced by Geger village. It also provides educational facilities related to biogas production and milk pasteurization that can be experienced directly during the visit. Milk will be processed into several products, such as yoghurt and milk with various flavors. There are also milk crackers, milk sticks and milk candy. According to Tong, et al. (2016), in recent years, tourists have increasingly emphasized the importance of culinary or food experiences when choosing tourist destinations. The second potency is historical tourism, known as Mbah Bodo grave site which located close to Arga Wilis guesthouse. There are collections of statues in the grave. Sendang village always holds a 
traditional ceremony called Siraman Barongan every August 17th. This ceremony is a splash event carried out by traditional elders to all artists in Sendang district. According to Noonan (2017), the diversity of tourist attractions can appeal tourists' interest to stay longer. As cultural tourism, a tour in Sendang village will be able to broaden life's views and experiences by learning customs, historical heritage, religious ceremonies, activities of the local community, and works produced.
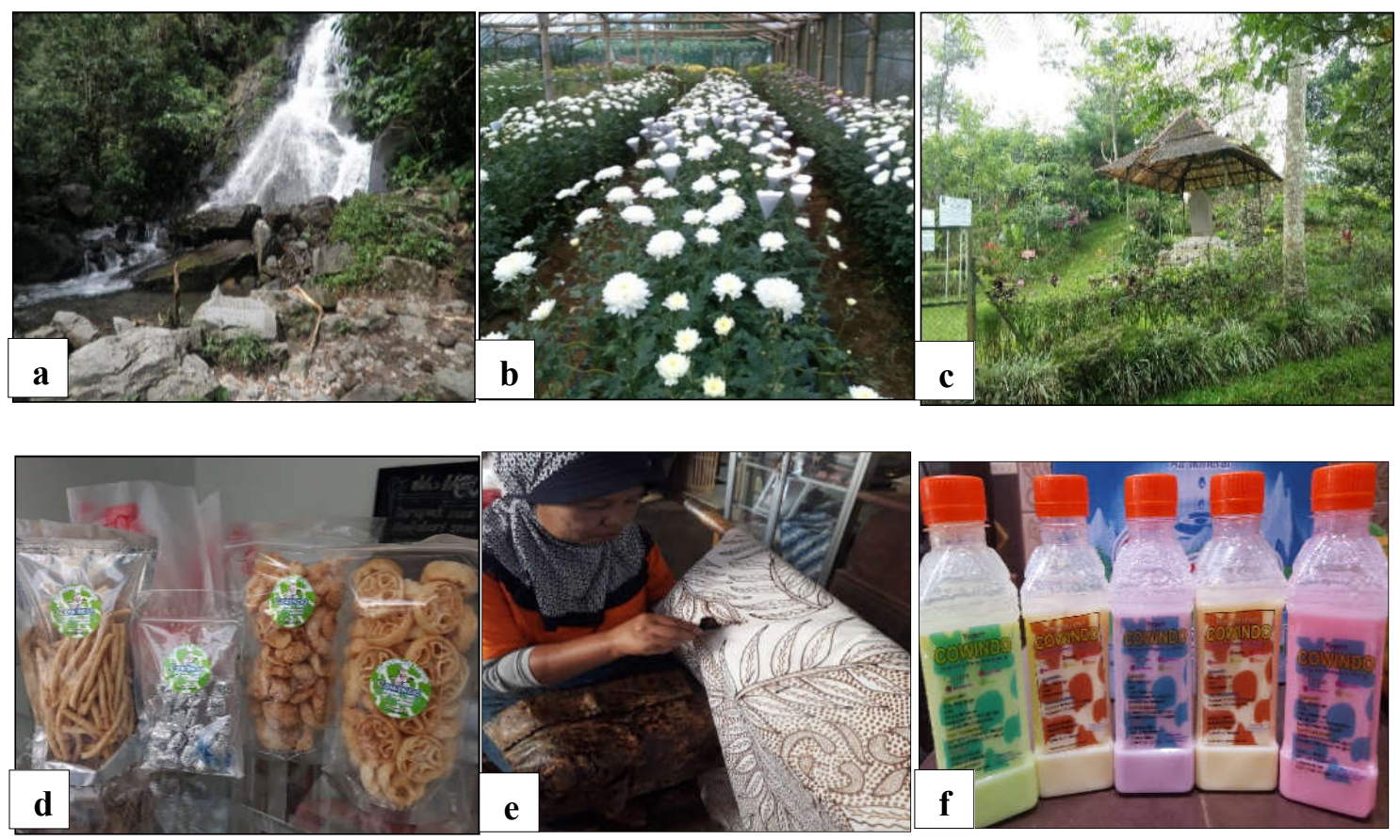

Figure 2- The potential tourism attraction of Agropolitan Sendang Area. (a) Lawean waterfall (b) Chrysanthemum flowers (c) Penampihan temple (d) Food product from livestock sector (e) Training on batik production (f) Milk and yoghurt products with various flavors

One of the best known craft in Tulungagung is "batik", produced in Sendang village. Batik from Sendang village has its own uniqueness as it is only producing "batik tulis", so each motif will be limited edition. There are various fabrics used, including cotton, satin, or silk with synthetic or natural dyes from leaves. The price is range from 250 thousand to million rupiah, depends on the fabric, motif, and coloring ordered. Tourists can observe and self-experience the process of making batik. According to Nyawo and Mubangizi (2015), the growth of the tourism industry can be considered as successful if a tourist area has a stable business growth, one of it is through art and craft market. The presence of craft SMEs product has the potential to provide job vacancy for local residents. The craft sector is very instrumental in the development and growth of rural economies.

Agrotourism Development Strategy in Agropolitan Sendang Area. Direction for the strategy of developing agrotourism in Agropolitan Sendang Area was determined using SWOT analysis. After identifying the potential, the next stage was performing analysis by assessing internal and external factors using the IFAS and EFAS matrix. Based on the table, the value of internal factor strength (S) and weakness (W) are 1.94 and 1.55 , respectively (Table 3). Sendang district has unspoiled tourism potential. Moreover, the community of Sendang district has began to understand the concept of agrotourism and support the development of agrotourism. This is proven by the openness of the community to tourists. The example of community's participation is renting homestay. It's also evidence that the community is aware of the business opportunities that will be generated. This involvement is important to improve the quality and living standards, tourist expectations, protection of nature and culture (Katarzyna, 2010). 
Table 3 - Internal Strategy Factor Analysis

\begin{tabular}{lccc}
\hline \multicolumn{1}{c}{ Internal Factor } & Weight & Rating & Score \\
\hline Strenght (S) & & \\
Community response to the development of agrotourism in the Agroplitan Sendang & 0.09 & 3 \\
Area & 0.08 & 3 & 0.27 \\
The openness of the community to accepts tourists & 0.09 & 4 & 0.36 \\
The participation of Agropolitan Sendang Area towards the agrotourism development & 3 & 0.24 \\
The existence of community economic motivation in the Agropolitan Sendang Area to & 0.08 & 3 \\
increase their income & 0.08 & 3 & 0.24 \\
The presense of traditional arts and historical relics in the Agropolitan Sendang Area & 0.08 & 4 & 0.32 \\
Tourism potential in the Agropolitan Sendang area is still natural & 0.09 & 3 & 0.27 \\
Community understanding of agrotourism & 0.59 & 1.94 \\
\hline$\quad$ Total & 0.09 & 4 & 0.36 \\
\hline Weakness (W) & 0.09 & 4 & 0.36 \\
Lack of promotion & 0.08 & 3 & 0.24 \\
lack of adequate accessibility to the Agropolitan Sendang area & 0.09 & 3 & 0.27 \\
location of Agropolitan area far from the center of Tulungagung regency & 0.08 & 4 & 0.32 \\
Agropolitan area doesn't have garbage dump or landfills & 0.43 & 1.55 \\
Lack of community interest in managing craft & Total & &
\end{tabular}

However, community knowledge about agrotourism management is still very lacking, so it's still constrained in promoting agrotourism. Therefore, it is necessary to hold socialization for the community with experts, so that the development of agrotourism runs optimally. In addition, the community also needs the participation of both central and village government to support the development activities. Adequate facilities will provide comfort and convenience for tourists, just as explained by Pratiwi. et al (2016).

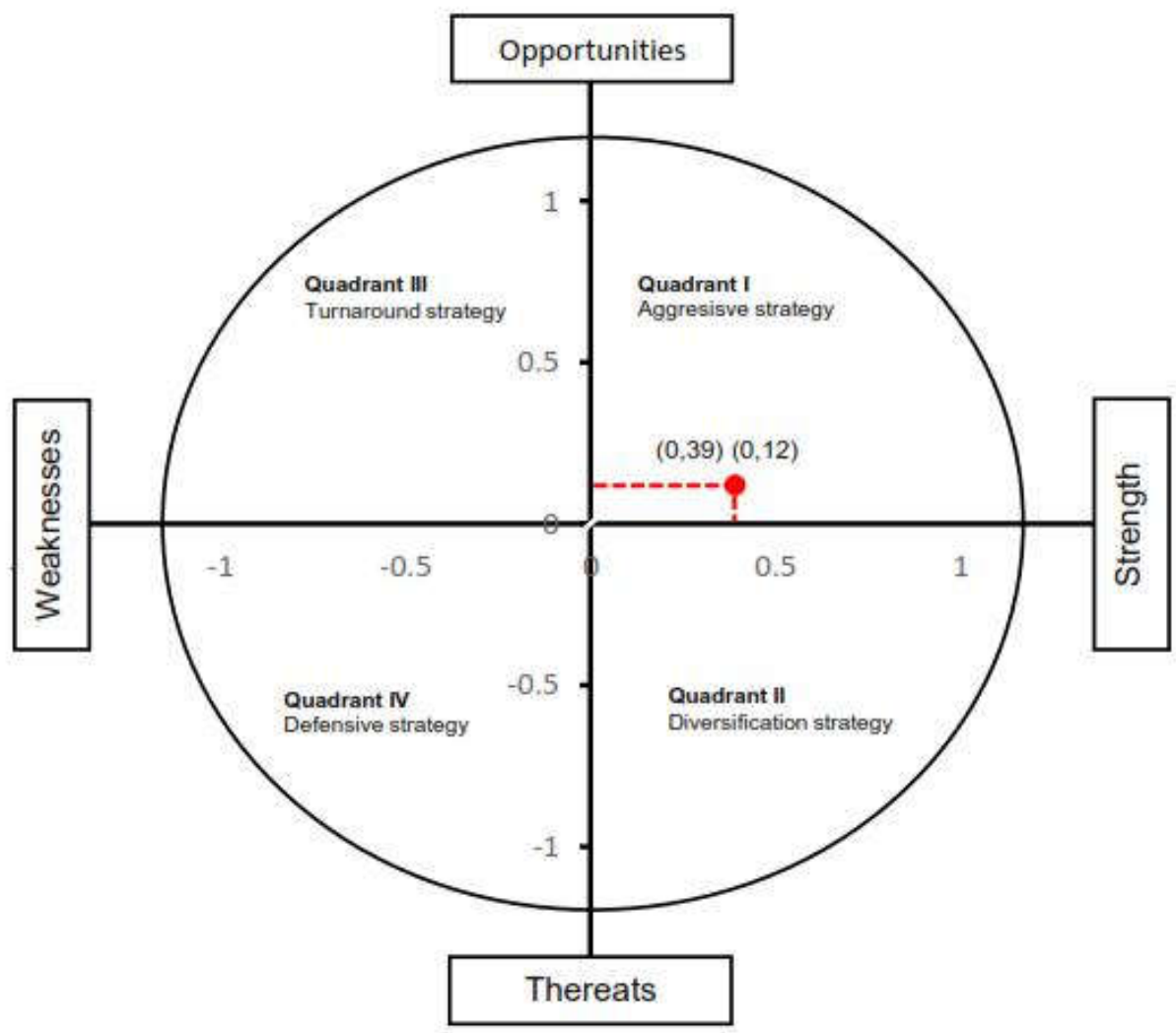

Figure 3- Agropolitan Sendang Area on IFAS-EFAS Analysis Strategy Quadrant

The results are that the external factor opportunity $(\mathrm{O})$ and threat $(\mathrm{T})$ have a value of 1.62 and 1.5, respectively (Table 4). Sendang district has abundant natural resources and various kinds of tourism potential. It can be considered as a great opportunity to develop 
agrotourism in Sendang District. In this case, both the government and community should be able to take advantage of the opportunities. They have along with maintaining the environmental sustainability. The existence of tourism development can give positive or negative impacts.

Table 4- External Strategy Factor Analysis

\begin{tabular}{|c|c|c|c|}
\hline External Factor & Weight & Rating & Score \\
\hline \multicolumn{4}{|l|}{ Opportunity (O) } \\
\hline It has variety of tourist attractions (natural, historical, reliqious, and culinary tourism) & 0.09 & 3 & 0.27 \\
\hline Compliance of the community of Agroolitan Sendang Region to community leaders & 0.08 & 3 & 0.24 \\
\hline The abundance of natural resources & 0.1 & 3 & 0.3 \\
\hline Potential tourists from domestic and abroad & 0.1 & 3 & 0.3 \\
\hline The role of communication media & 0.08 & 3 & 0.24 \\
\hline Opportunities are still open because only Sendang District is an Agropolitan Area & 0.09 & 3 & 0.27 \\
\hline Total & 0.54 & & 1.62 \\
\hline \multicolumn{4}{|l|}{ Threat $(T)$} \\
\hline $\begin{array}{l}\text { Lack of policies and participation from local governments that support the } \\
\text { development of agrotourism }\end{array}$ & 0.09 & 4 & 0.36 \\
\hline Community are less concerned about developing creativity & 0.1 & 3 & 0.3 \\
\hline There are still many community who do not care about the environment & 0.11 & 3 & 0.33 \\
\hline Road infrastructure to Sendang district that enters other Districts is still inadequate & 0.09 & 3 & 0.27 \\
\hline Educational background of the Sendang District community & 0.08 & 3 & 0.24 \\
\hline Total & 0.47 & & 1.5 \\
\hline
\end{tabular}

The positive impact is the development of new infrastructure that can be utilized by all parties, while the negative impact is the possibility of threatening environmental sustainability if the government and society do not make greater efforts to protect it. That one of the main tourist sites of a particular region consists of natural resources (Mogollon, et al., 2011). If the community has a low level of education regarding to the importance of environment sustainability, it's possible that the awareness to protect the nature will be low too. Therefore, the community needs the participation of the local government to help developing Sendang district.

SWOT quadrant analysis was combining the analysis of both internal and external factors. The goal is to get the quadrant position which will later be used as a reference for the development of agrotourism in the Agropolitan Area, Sendang District. The value was obtained from the differences within internal factor scores (strengths - weaknesses) and the differences within external factor scores (opportunities - threats) with the following calculations:

Strengths - Weaknesses $=1,94-1,55=0,39$;

Opportunities - Threats $=1,62-1,50=0,12$.

The analysis results show that the development of agrotourism in the Agropolitan Sendang Region was in the quadrant I position, using an aggressive strategy. This position is very profitable because the internal strength can be used to take advantage of various opportunities. Agropolitan Sendang area can continue to develop the existing potentials while reducing the weaknesses. The direction of the strategy for the development of agrotourism in the Agropolitan Sendang Area is explained below:

- Data collection, related to the development of tourism potential and objects of tourist attraction in the entire Sendang District. The collected potential data will facilitate the development effort by highlighting the distinct potential own by each village. This data also benefical to easily manage the development strategy, environmental damage and exploitation. Another advantage facilitating tourists to choose the desired tour easily.

- Improving the management by involving the local community, because they have an important role in planning, implementing, managing and evaluating the development strategy. This serves to provide an opportunity for the community to enjoy the benefits of the developed tourism. This kind of involvement will encourage the community to 
provide support and active participation in preserving the environment, since they have a sense of belonging to the potential that exists. In addition, it will also improve the quality of human resources related to tourism issues.

- Strengthening the synergy between local governments, private sector and surrounding communities. Synergy needs to be developed to create mutual agreement in efforts to conserve nature so that no damage will occur due to tourism development. Each institution has its own authority to preserve the environment. Without cooperation, the goal will be very difficult to achieve. Of course there must be formulations to provide solutions.

- Promotion and socialization by highlighting the strengths own by each region such as traditional arts or traditional ceremonies held in Sendang District. The participation of social media plays an important role in the process of promotion and socialization regarding to the development of agrotourism in Agropolitan Sendang Area. Socialization to the community is expected to increase people's understanding of agrotourism and its benefits. Besides that, it can support the quality improvement of human resources in the development of agrotourism. On the other hand, promotional efforts are expected to increase tourist visits to Agropolitan Sendang Area.

\section{CONCLUSION}

Based on the research that has been conducted, it can be concluded that out of 11 villages in Sendang district, there are two villages that have the most potential to be developed into agrotourism namely Geger Village and Sendang Village. Geger Village has potential in regard to agriculture, livestock, plantation, ornamental flower cultivation, nature, historical and cultural tourism. While Sendang Village has potential related to the livestock, historical tourism, the arts and crafts sector. Geger village is famous for its agricultural products while Sendang Village is famous for its livestock products.

Directions for the development strategy of agrotourism in Sendang district including: data collection of tourism potential and tourist attraction objects; improve the management by involving the community; strengthen the synergy between local governments, private sector, and the surrounding community; actively conduct promotions and socialization.

\section{REFERENCES}

1. Baffes, J. 2005. Tanzania's Coffee Sector: Constrains and Challenges. Journal of International Development. Vol. 17, page. 21-43

2. Buang, A., A. Habibah, J. Hamzah, dan Y.S. Ratnawati. 2011. "The Agropolitan Way of Re-Empowering The Rural Poor". World Applied Science Journal. Vol. 13, page. 01-06.

3. Farhanah, L. dan S.D.W. Prajanti. 2015. Strategies in Developing Agropolitan Area in Indonesia. Jurnal Ekonomi Pembangunan. Vol.16 (2), page. 158-165.

4. Fleischer, A. and Tchetchik, A. 2006. Does Rural Tourism Benefit from Agriculture. Journal Of Tourism Management. Vol. 26 (4), page. 493-501.

5. Katarzyna, DG. 2010. Lakes, Reservoir and Regional Development through Some Examples in Poland and Hungary. GeoJournal of Tourism and Geosites.Vol. 5 (1), page. 16-23

6. Koththagoda, K.C dan Dissanayake, D.M.R. 2017. Potential of Tea Tourism in SriLanka: A Review on Managerial Implications and Research Directions. Journal of Equality and Management. page. 51-68.

7. Mogollon, J.MH., A.M.C. Cerro, F.L. Berrocal., A.P.Diaz. 2011. Agricultural Diversification and The Sustainability of Agricultural Systems: Possibilities for The Development of Agrotourism. Journal of Environmental Engineering and Management. Vol. 10 (12), page.1911-1921.

8. Noonan, D.S. 2017. Economics of Cultural Tourism Issues and Perspective. Journal of Cultural Economics. Vol. 41 (2), page. 95-107. 
9. Nyawo, J. dan B.C. Mubangizi. 2015. Art and Craft in Local Economic Development: Tourism Possibilities in Mtubatuba Local Municipality. Journal of Hospitally, Tourism and Leisure. Vol. 4 (2), page. 1-15.

10. Parmawati, R., R. Imaniyah., L.E. Rokani., M.I. Rajaguni., A.S. Kurnianto. Ecotourism Development Strategy of Bukit Jaddih Karst, Madura. Journal of Indonesian Tourism and Development Studies. Vol. 6 (2), page. 113-119.

11. Prasetio, B. 2010. 23 Peluang Usaha Top Bidang Agribisnis. ANDI publisher. Yogyakarta.

12. Prasetiya, A., Suyadi, M. Bisri. Soemarno. 2015. Development Strategy of Sendang Agropolitan Area, Tulungagung. International Journal of Applied Sociology. Vol. 5 (3), page. 113-120.

13. Pratiwi, A., N.Aini., K.P. Wicaksono. Analysis Of Agricultural Cultivation as An Attraction for Rural Agrotourism. Journal of Agriculture and Veterinary Science. Vol. 7 (1), page. 6780.

14. Region Regulation of Tulungagung No.24 in 2004 about "Penetapan Kawasan Strategis Cepat Tumbuh Kabupaten Tulungagung"

15. Srivastava, S. 2016. Agrotourism as a Strategy for the Development of Rural Areas Case Study of Dungrajya Village, Southest Rajasthan, India. Journal Of Research In Humanities And Sosial Science. Vol. 4 (7), page. 104-108.

16. Sunfianah, L. dan A. Haryono. 2014. "Pelaksanaan Pengembangan Kawasan Agropolitan Kabupaten Malang (Studi Kasus Kecamatan Poncokusumo)". JESP. Vol. 6 (2), page. 230-238.

17. Syahrani, H.A.H. 2001. "Penerapan Agropolitan dan Agribisnis dalam Pembangunan Ekonomi Daerah. FRONTIR. No. 33.

18. Tong, X.F., D.Y.K Tong, dan W.S Tam. 2016. Food Tourism: The Melaka Gastronomic Experience. Jounal of Emerging Trends in Marketing and Management. Vol. 1, page. 236-246. 